\title{
economics-of-security.eu
}

Sami Miaari, Asaf Zussman and Noam Zussman

\section{Employment Restrictions and Political Violence in the Israeli-Palestinian Conflict}

January 2012

Economics of Security Working Paper 59

This publication is an output of EUSECON, a research project supported by the European Commission's Seventh Framework Programme.

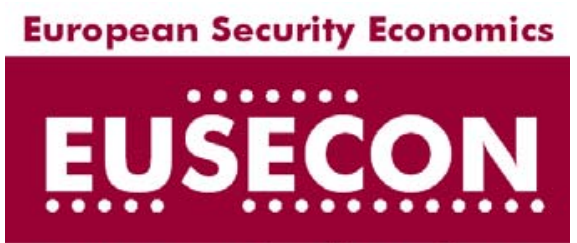

www.economics-of-security.eu

Economics of Security is an initiative managed by DIW Berlin 
Correct citation: Miaari, S. et al. (2012). "Employment Restrictions and Political Violence in the Israeli-Palestinian Conflict". Economics of Security Working Paper 59, Berlin: Economics of Security.

First published in 2012

(C) Sami Miaari, Asaf Zussman, Noam Zussman 2012

ISSN: 1868-0488

For further information, please contact:

Economics of Security, c/o Department of Development and Security, DIW Berlin - German Institute for Economic Research, Mohrenstr. 58, 10117 Berlin, Germany.

Tel: +49 (0)30 $89789-277$

Email: eusecon@diw.de

Website: www.economics-of-security.eu 


\title{
Employment Restrictions and Political Violence in the Israeli-Palestinian Conflict*
}

\author{
Sami Miaari \\ Haifa University, \\ Ono Academic College, \\ and DIW Berlin
}

\author{
Asaf Zussman ${ }^{\dagger}$ \\ The Hebrew University Bank of Israel \\ of Jerusalem \\ Noam Zussman
}

December 29, 2011

\begin{abstract}
Following the outbreak of the Second Intifada in 2000, Israel imposed severe restrictions on the employment of Palestinians within its borders. We study the effect of this policy change on the involvement of West Bank Palestinians in fatal confrontations during the first phase of the Intifada. Identification relies on the fact that variation in the pre-Intifada employment rate in Israel across Palestinian localities was not only considerable but also unrelated to prior levels of involvement in the conflict. We find robust evidence that localities that suffered from a sharper drop in employment opportunities were more heavily involved in the conflict.
\end{abstract}

JEL classification code: F52, H56, J23, J48.

Keywords: Employment Restrictions, Political Violence, Israeli-Palestinian Conflict.

*We thank Haggay Etkes, Daniele Paserman, Yael Berda, and participants of a seminar at the Bank of Israel for many valuable comments, Aharon Barazani for his help with the data, and Hadar Divish for research assistance. The views expressed in this paper are those of the authors and do not necessarily reflect the position of the Bank of Israel. Sami Miaari thanks the European Union Seventh Framework Programme under grant agreement no. 218105 (EUSECON) for funding his stay in DIW-Berlin while he was working on this project.

${ }^{\dagger}$ Corresponding author. Address: Department of Economics, The Hebrew University of Jerusalem, Mount Scopus, Jerusalem 91905, Israel. E-mail: azussman@mscc.huji.ac.il. 


\section{Introduction}

Do economic conditions affect political violence? The answer to this question has important implications for understanding the root causes of violence and may guide policies aimed at countering violence. Conventional wisdom seems to hold that improving economic conditions have the potential to reduce violence by raising the opportunity cost of involvement in violent activities. The United States government, for example, adopted this view and has taken measures to improve the economic conditions of local populations in conflict areas such as Afghanistan and Iraq. Nevertheless, research has not reached a consensus yet as to whether there is a causal link between economic conditions and involvement in political violence.

This paper contributes to the debate by providing new evidence from the Israeli-Palestinian conflict. Following the outbreak of the Second Intifada in the fall of 2000, Israel immediately imposed severe restrictions on the employment of Palestinians within its borders. In this paper we analyze the effect of this policy change on Palestinian involvement in the conflict with Israel.

The employment of Palestinians in Israel started shortly after the Israeli occupation of the Territories (the West Bank and the Gaza Strip) in the 1967 war. The architect of economic integration between the Territories and Israel was the then Defense Minister, Moshe Dayan. At the time, supporters of the policy argued that Israel must take responsibility for the welfare of the Palestinians living in the Territories and therefore should allow them to work in Israel. Those opposed to the policy were concerned, among other things, that by allowing easier access to Israel, security would be compromised. Supporters of the integration policy raised a counter argument: that higher incomes and lower unemployment in the Territories would lower Palestinian resistance to the Israeli occupation. Dependence on employment in Israel, it was argued, would deter Palestinians from getting involved in the conflict. Thus, from the perspective of Israel's policy makers, Palestinian employment in Israel served simultaneously as both a carrot and a stick (Gazit, 1995). The pros and cons of Palestinian employment in Israel have been debated at the highest levels of Israeli government ever since. Yet until now there has been no empirical research on the causal relationship between the Israeli employment policy and Palestinian involvement in the conflict with Israel.

Our ability to credibly explore the impact of employment restrictions on conflict intensity rests on several key facts. First, employment in Israel was very important for the welfare of the Palestinian population: on the eve of the Second Intifada, income from this source accounted for one sixth of Palestinian national income (Palestinian Central Bureau of Statistics, 2003). Second, at that time, the share of those employed in Israel out of total population (henceforth "employment rate") exhibited considerable variation across Palestinian 
localities. Third, as our analysis shows, before the outbreak of the Intifada employment rates across localities were unrelated to levels of involvement in the Israeli-Palestinian conflict. Fourth, following the outbreak of the Intifada, and with the aim of preventing attacks against Israelis, the government of Israel decided to drastically restrict (effectively almost completely banning) Palestinian employment in Israel. Thus the abrupt, drastic, and exogenous Israeli policy change had a differential effect on the employment opportunities of Palestinians residing in different localities.

Relying on this "natural experiment" and using a rich new dataset - which includes Israeli administrative data on each and every Palestinian employed in Israel with a permit, Palestinian labor force surveys, Palestinian census data on the economic and socio-demographic characteristics of localities, pre-intifada voting patterns in the Palestinian Authority, the number of Palestinian fatalities and more - this paper examines the causal relationship between employment restrictions and political violence. The analysis, which is carried out at the locality level, focuses on 20-49 year old male employees from the West Bank and on Palestinian fatalities in the first phase of the Intifada.

The main result of the analysis is that employment restrictions increase involvement in the conflict: localities that saw sharper declines in employment rates had greater numbers of Palestinian fatalities. All else being equal, at the locality level, a one percentage point decline in the employment rate was associated with a 0.12 increase in Palestinian fatalities. Overall, employment restrictions explain roughly one fifth of the total number of fatalities. We also find that involvement in the conflict increased with the locality's level of education and that it was influenced more by declines in the employment of younger workers - two results which are consistent with the existing literature. An additional finding is that the decline in employment of younger workers affected the number of combatant fatalities more than the number of civilian fatalities.

Taken as a whole, the results of this study seem to suggest that improving the welfare of Palestinians by allowing them to work in Israel may reduce their involvement in the conflict with Israel. However, due to the following data and methodological limitations the results of the analysis should be interpreted with care. First, involvement in the conflict is proxied here by the number of Palestinian fatalities. However, it is clear that some of fatalities are not due to involvement in political violence and that many incidents of violence do not end up costing lives. Second, our analysis does not take into account actions by the Israeli (and Palestinian) security forces aimed at reducing violence. Third, the study does not provide a counterfactual, i.e., we do not know what the intensity of the conflict would have been had Israel not decided to restrict Palestinian employment. Furthermore, we relate variation in employment declines to variation in conflict intensity, but we cannot estimate the effect of 
the policy change on the overall level of violence. Our analysis also ignores the question of the "cycle of violence", i.e., whether and to what extent Israel reacts to Israeli fatalities and the Palestinians react to Palestinian fatalities. ${ }^{1}$ The paper focuses on the effect of employment declines on involvement in conflict; the effect of employment increases may not necessarily be symmetric. Finally, our study focuses on the Israeli-Palestinian conflict and on a specific policy intervention. We do not know whether the study's results would carry over to other conflicts and to other policies used to reduce violence.

Our study contributes to the small but growing literature on (a) the causal effect of economic conditions on conflict and (b) the effectiveness of measures aimed at countering political violence. We exploit a "natural experiment" and rely on high quality data, which increases the credibility of identification by overcoming methodological obstacles that plague the literature.

The rest of the paper is organized as follows. Section 2 reviews the relevant literature. Section 3 explains how we constructed the dataset used in the analysis. The first part of Section 4 describes patterns of Palestinian employment in Israel and estimates, at the locality level, the determinants of employment in Israel during the pre-Intifada period. The second part of Section 4 focuses on political and economic developments in the West Bank following the outbreak of the Intifada. Section 5 is devoted to estimating the effect of employment restrictions on conflict intensity. Section 6 summarizes the results and provides concluding remarks.

\section{Existing literature}

This paper is related to two strands of the literature on conflict. The first investigates the relationship between economic conditions and conflict. ${ }^{2}$ The second examines the effectiveness of policies aimed at countering political violence.

Research on the relationship between economic conditions and political violence largely focuses on testing the following hypothesis: that poor economic conditions (e.g. low levels of income or high levels of unemployment) lower the opportunity cost of involvement in political violence and breed frustration, despair and instability, all of which make it easier to garner support for - and motivate active participation in - political violence. Despite the simplicity and intuitiveness of this hypothesis, empirical research has not yielded consistent results: studies - most of which rely on cross-sectional variation between countries - find

\footnotetext{
${ }^{1}$ See Jaeger and Paserman (2008) and Haushofer et al. (2010) for analyses of this question.

${ }^{2}$ We focus here on research dealing with low intensity conflict (insurgency, guerrilla warfare, terrorism, etc.) and completely abstract from the large separate literature (e.g., Miguel et al., 2004) which looks at the relationship between economic conditions and wars.
} 
that better economic conditions are associated either with less violence (e.g., Blomberg et al., 2004; Tavares, 2004), the same level of violence (e.g., Abadie, 2006; Krueger and Laitin, 2008), or even more violence (e.g., Berman et al., 2009).

Three previous studies have examined the relationship between economic conditions and the involvement of Palestinians in the conflict with Israel. Taking the Territories as a single unit of observation and examining time series variation for the period 1990-2002, Saleh (2004, 2009) shows that deterioration in economic conditions (higher unemployment and lower income) were associated with more attacks against Israelis. Employing a similar methodology for the same period, Sayre (2009) finds a positive association between the unemployment rate among younger Palestinian workers and the number of suicide bombings, but no association for other economic indicators and measures of violence intensity.

The literature on the effectiveness of policies aimed at countering political violence is relatively thin. Some studies examine the effectiveness of offensive military measures. For example, using time-series techniques, Enders and Sandler (1993) find that the 1986 United States bombing in Libya led to a short run increase in attacks directed at American and British targets. Lyall (2009) exploits random variation in the severity of Russian shelling of Chechen villages during 2000-05 to show that increased shelling led to a decline in the intensity of Chechen attacks against the Russians and their allies. Two recent studies have examined the effectiveness of economic measures taken by the United States in Iraq. Berman et al. (2011) find that funding of small scale public projects was effective in reducing attacks against allied forces. Iyengar et al. (2011) show that funding projects which intensively use local labor had conflicting effects: it decreased insurgent attacks against civilians but increased attacks against military targets.

Several studies have focused on the effectiveness of measures taken by Israel in its conflict with the Palestinians. Brophy-Baermann and Conybeare (1994) report that out of all the measures taken by Israel in the 1970s and 1980s, only the surprisingly strong reaction to the killing of its athletes in the 1972 Olympics was effective in reducing violence. Kaplan et al. (2005) find that mass preemptive arrests of Palestinians carried out by Israel during the Second Intifada led to a decrease in the number of Palestinian suicide bombings. Zussman and Zussman (2006) show that Israeli assassinations of leaders in the military wings of Palestinian organizations during the Second Intifada were viewed by investors in the Israeli stock market as effective measures in reducing violence; in contrast, assassinations of leaders in the political wings of these organizations were viewed as counter-productive. Finally, Benmelech et al. (2010) demonstrate that the demolition of houses of Palestinians suicide bombers during the second Intifada had a short run negative influence on the number of suicide bombings; in contrast, the demolition of houses due to building code violations had 
the opposite effect.

We believe that our study makes a contribution to both strands of the literature on political violence. In particular, many studies in the literature suffer from potentially severe methodological problems, including omitted variables bias (differences across countries and conflicts which are not taken into account in the analysis), reverse causation (conflict intensity affecting economic conditions), or non-random implementation of measures to counter violence. In contrast, our study relies on what seems to be a relatively clean "natural experiment" which makes it possible to credibly identify causal relationships.

\section{Dataset}

We combine data from several sources which provide information on Palestinian employment in Israel, the Palestinian labor market, economic and socio-demographic characteristics of Palestinian localities, voting patterns in the Palestinian Authority, and Palestinian fatalities in the conflict with Israel. All this information was aggregated, when necessary, to the level of the locality, which serves as the unit of analysis.

We obtained monthly administrative data on all Palestinians employed in Israel with a permit in the years 1998-2008. The data was provided by the Israeli Ministry of Industry, Trade and Labor, which is in charge of issuing the permits. For each Palestinian employee we have information on locality of residence, age, and gender. We obtained additional information on the labor market in the Territories from labor force surveys conducted quarterly by the Palestinian Central Bureau of Statistics (PCBS). Economic and socio-demographic characteristics of Palestinian localities were taken from the population census conducted by the PCBS at the end of $1997 .^{3}$ The Palestinian Central Elections Committee provided us with results of the elections for the presidency of the Palestinian National Authority held in January 1996. Geographic coordinates of Palestinian (and Israeli) localities are from the Israeli Central Bureau of Statistics (ICBS).

This study focuses on localities in the West Bank (i.e., it excludes localities in the Gaza Strip) for the following reasons: (a) the 24 localities in the Gaza Strip (according to the ICBS) are characterized by geographic contiguity, which makes the distinction between them essentially artificial; (b) most Israeli settlements in the Gaza Strip and the roads leading to them were separated from Palestinian localities. Thus contact between Palestinians and Israeli civilians and security forces during the Second Intifada was much less intense in the Gaza Strip than in the West Bank.

\footnotetext{
${ }^{3}$ Detailed information on the labor force surveys and the population census can be found on the website of the PCBS at www.pcbs.gov.ps.
} 
Our dataset includes 373 Palestinian localities in the West Bank. These are all the localities that appear both in the list of localities of the ICBS and in the list of localities of the PCBS, except for 34 localities which have a population of less than 200 persons. We exclude these smaller localities because the reliability of economic and socio-demographic data for them is low. ${ }^{4}$ According to the 1997 census conducted by the PCBS, the localities included in the dataset contain 92 percent of the total West Bank population (excluding East Jerusalem). ${ }^{5}$

We obtained information on Palestinian fatalities during the first phase of the Intifada (September 2000 - March 2002) from B'Tselem (The Israeli Information Center for Human Rights in the Occupied Territories) and from the International Institute for CounterTerrorism (ICT) at the Interdisciplinary Center, Herzliya. The latter source also provided the breakdown of fatalities into civilians and combatants: combatants are defined as those who carried or used firearms, explosive devices, hand grenades or Molotov cocktails as well as uniformed members of the Palestinian security forces. We further gathered information on Palestinian fatalities from the signing of the Oslo accords in September 1993 until the outbreak of the Second Intifada from B'Tselem and cross-checked it against articles published in Israeli daily newspapers Ha'aretz and Yedioth Ahronoth.

During the first eighteen months of the Intifada there were 831 Palestinian fatalities (510 civilians and 321 combatants, including 47 suicide bombers, most of whom blew themselves up in Israel) in the West Bank localities included in our dataset. This figure translates into roughly 5 fatalities per 10,000 population. More than 95 percent of the fatalities were males. The median age of the fatalities was 24 (less than 5 percent were 50 or older). Summary statistics for key variables at the locality level are provided in Table 1.

[Table 1]

\section{Palestinian employment in Israel}

\subsection{Before the Second Intifada}

The employment of Palestinians in Israel began almost immediately after the Israeli occupation of the Territories in 1967. A major rationale for the policy was that allowing

\footnotetext{
${ }^{4}$ According to the ICBS, before the outbreak of the Second Intifada there were 485 Palestinian localities in the West Bank (excluding East Jerusalem). According to the PCBS, in 1997 (when the census was conducted) there were 692 localities in the West Bank (including East Jerusalem). Almost all of the discrepancy between the two sources is due to settlements consisting of several huts and tents which are defined as localities by the PCBS.

${ }^{5}$ Palestinians residing in East Jerusalem, unlike those residing in the West Bank, do not need a permit to work in Israel, and are therefore excluded from the analysis.
} 
Palestinians to work in Israel would improve economic conditions in the Territories and thus reduce resistance to the occupation. Concern over losing this employment opportunity, it was believed, would deter Palestinians from getting involved in anti-Israeli activities. The number of Palestinians employed in Israel since then has been determined by political and economic considerations, separately for the West Bank and the Gaza Strip, and by the economic sector of the Israeli employer. Since the early 1990s Palestinians are granted work permits on individual basis. To obtain work permits for Palestinian workers, Israeli employers submit petitions to the Israeli Ministry of Industry, Trade and Labor; permits are issued subject to security screening of each prospective Palestinian employee. ${ }^{6}$ For more details on this procedure see Mundlak (2000), State of Israel (2011) and Berda (forthcoming).

There are no publicly available sources which detail the guidelines for granting employment permits and thus help to account for variation in the employment rate across Palestinian localities. However, officials from the Israeli Ministry of Industry, Trade and Labor suggested, in conversations with us, that the matching between Israeli employers and prospective Palestinian employees is in many cases facilitated by Palestinians already working for these employers. The Palestinian employees typically recruit relatives and friends from their own locality. This networking effect generates path dependency. An additional explanation for variation across localities in the employment rate is specialization: some localities specialize in specific jobs (e.g., employees from the Hebron area specialize in marble masonry) which are in high demand in Israel.

Employment in Israel has been a major source of income for the Palestinians - on the eve of the Second Intifada 146 thousand Palestinians from the West Bank and the Gaza Strip were employed in Israel (and in Israeli settlements in the Territories), roughly 22 percent of total employment in the Territories (Palestinian Central Bureau of Statistics, 2000). Income from this source accounted for roughly one sixth of Palestinian national income (Palestinian Central Bureau of Statistics, 2003).

According to administrative data provided by the Israeli Ministry of Industry, Trade and Labor, on the eve of the Second Intifada about thirteen thousand Palestinians from the West Bank, almost all male, worked in Israel with a permit (Figure 1). ${ }^{7}$ Palestinian males

\footnotetext{
${ }^{6}$ At the time the Second Intifada broke out, there were only several thousand West Bank Palestinians who where specifically prohibited, for security reasons, from working in Israel (Berda, forthcoming).

${ }^{7}$ According to the Palestinian labor force survey for the third quarter of 2000, 82 thousand Palestinians from the West Bank (excluding East Jerusalem) were employed by Israelis: 20 thousand in Israel proper with a permit and 8 thousand in Israeli settlements in the West Bank. It is important to note that the reliability of the data on Palestinian employment by permit is higher in the administrative records that we rely on (see Mansour, 2010).

The labor force survey of the third quarter of 2000 shows that the correlation across localities between employment in Israel with and without a permit is high (0.75). Possible explanations for this pattern include networking (i.e. arranging work through family or friends) and common transportation arrangements.
} 
employed in Israel with a permit made up about 5 percent of the total working age male population and roughly 10 percent of all employed males (Table 1).

\section{[Figure 1]}

The employment rate varied considerably across West Bank districts (Appendix figure 1A) and localities. Evidence shows that localities closer to Israel had a higher employment rate (Figures $2 \mathrm{~A}$ and $2 \mathrm{~B}$ ). This is likely due to the fact that Palestinian workers were not allowed to stay over-night in Israel and the fact that travel is costly. Another pattern evident in the data is that employment rates were higher in villages than in cities and refugee camps (which are typically located on the outskirts of cities): before the outbreak of the Intifada the average employment rate of males ages 20-49 was 6 percent in villages and only 4 percent in cities and refugee camps. ${ }^{8}$ This difference is likely due to fewer employment opportunities in villages.

\section{[Figures 2A and 2B]}

Our analysis focuses on estimating the effect of the employment restrictions imposed by Israel following the outbreak of the Second Intifada on Palestinian involvement in the conflict. These estimates would be biased, however, if there is correlation at the locality level between the pre-Intifada employment rate and the propensity of residents to be involved in the conflict. For example, if the issuance of permits favored localities that were perceived as more supportive of the peace process with Israel, then our estimates could potentially be biased downwards.

As mentioned above, officials at the Israeli Ministry of Industry, Trade and Labor and researchers (e.g., Berda, forthcoming) contend that the issuance of permits is independent of such considerations and is mostly driven by two factors (a) networking, i.e., current Palestinian workers attempt to arrange permits for family and friends from their own locality, and (b) demand for workers with specific skills.

To investigate this potential source of bias more rigorously we estimate the following equation:

$$
E R_{i}=\alpha_{0}+\alpha_{1} \log D_{i}+\alpha_{2} P_{i}+\alpha_{3} U_{i}+\alpha_{4} R C_{i}+\alpha_{5} A_{i}+\alpha_{6} F R(-1)_{i}+\epsilon_{i}
$$

where $E R_{i}$ is the employment rate in Israel of Palestinian males ages 20-49 (in other words, the number of those employed in Israel with a permit out of total male population ages 20-49)

\footnotetext{
${ }^{8}$ Very few permits were issued to Palestinian males in the 18-19 age group; less than 10 percent of Palestinian males employed in Israel were 50 or older.
} 
in locality $i$, averaged over the period October 1998 -September $2000^{9}, D_{i}$ is the distance to Israel, $P_{i}$ is locality population, $U_{i}$ is an indicator for urban localities, $R C_{i}$ is an indicator for refugee camps, $A_{i}$ is the percentage support for Yasser Arafat in elections for the presidency of the Palestinian National Authority held in January 1996, $F R(-1)_{i}$ is the rate (share in percent) of Palestinian fatalities in the conflict with Israel from the signing of the Oslo accords (September 13, 1993) until the outbreak of the Second Intifada (September 28, 2000) out of total locality population, and $\epsilon_{i}$ is a well-behaved error term.

Results presented in Table 2 show that distance from Israel is strongly and negatively correlated with the employment rate: a one percent increase in distance is associated with a 2 percentage point decline in the employment rate. We also find that the employment rate is about 1.5 percentage points (or roughly one third) lower in cities and refugee camps than in villages. ${ }^{10}$

In columns 2 through 6 we add variables that attempt to capture, at the locality level, the propensity to be involved in the conflict with Israel. The first variable we add is the percentage support for Yasser Arafat in elections for the presidency of the Palestinian National Authority held in January 1996. A major issue on the agenda during these elections was support for the Oslo Accords signed in 1993 between Israel and the Palestine Liberation Organization (PLO) and follow-up agreements. The purpose of these agreements was to peacefully resolve the Israeli-Palestinian conflict and to establish an independent Palestinian state alongside Israel. The agreements were supported by the PLO and its chairman, Yasser Arafat, but opposed by Islamic organizations (such as Hamas) and others. The results presented in column 2 show that support for Arafat was not significantly correlated with the employment rate. $^{11}$

We next add to the baseline regressors the share (in percent) of Palestinian fatalities in the conflict with Israel from the signing of the Oslo accords until the outbreak of the Second Intifada out of total locality population. We find that combatant fatalities (column 3), civilian fatalities (column 4) and total fatalities (column 5) are all uncorrelated with the pre-Intifada employment rate. ${ }^{12}$ Adding both the Arafat variable and the total fatalities

\footnotetext{
${ }^{9}$ We average the employment rate over this two year period to capture long-run pre-Intifada employment patterns. We note that employment in Israel was highly persistent, and thus the results of estimating equation (1) do not change much when the employment rate is averaged over the period just before the outbreak of the Intifada.

${ }^{10}$ The difference between the estimated coefficients for cities and refugee camps is statistically insignificant.

${ }^{11}$ It is possible that public opinion changed from January 1996 to September 2000. However, we do not find strong evidence for this actually happening. Comprehensive public opinion polls conducted by Bir Zeit University researchers show that the correlation (at the district level in the West Bank) between the extent of support for Arafat in January 1996 and in September 2000 is 0.46.

${ }^{12}$ During the pre-Intifada period, 199 West Bank (excluding East Jerusalem) Palestinians were killed by Israelis: 63 combatants, 129 civilians, and 7 unclassified.
} 
variable to the baseline regression yields the same qualitative results (column 6). ${ }^{13}$

In sum, we find no evidence of locality-level correlation between the pre-Intifada employment rate and key factors that plausibly capture the propensity of residents to be involved in the conflict with Israel. This reinforces the credibility of our identification strategy.

\subsection{The Second Intifada}

The years preceding the outbreak of the Second Intifada were characterized by relative calm in the Israeli-Palestinian conflict (Figures 3A and 3B). The Second (or Al-Aqsa) Intifada broke out on September 28, 2000 and eventually claimed the lives of thousands of Palestinians and Israelis. At the end of March 2002, a month that saw a peak in the number of Israeli fatalities, Israel launched a military operation ("Defensive Shield") in which large scale forces took over Palestinian localities, conducted mass arrests and set up a large number of military posts and roadblocks. The operation marked a turning point in the evolution of the Intifada, eventually leading to a sharp decline in Israeli and Palestinian fatalities. We chose to limit our analysis to the pre-"Defensive Shield" period because it had such a drastic effect on the turn of events.

\section{[Figures 3A and 3B]}

During the period from the outbreak of the Intifada until the start of operation "Defensive Shield", 831 Palestinian residents of West Bank localities included in our dataset were killed by Israelis: 510 civilians and 321 combatants (47 of them suicide bombers). During the same period 148 Israelis were killed by Palestinians in the West Bank.

Following the outbreak of the Intifada, the number of Palestinians from the West Bank (and the Gaza Strip) employed in Israel dropped sharply (see Figure 1 above). The number of days worked by these employees dropped even more drastically (see Appendix Figure 2A), as the average number of work days per month declined. This was due to the Israeli policy of intermittently imposing curfews and closures, which made it more difficult for permit-holders

\footnotetext{
${ }^{13}$ We conducted two additional tests of the hypothesis that localities more supportive of the peace process with Israel were issued relatively more permits. One possible indication at the locality level of preferential treatment by the Israeli authorities is connection to public utilities, such as electricity, water, sewage and landline telephones (information was taken from Palestinian Central Bureau of Statistics, 1999). Adding indicators for such connections to equation (1) yields insignificant results.

According to the theory of club goods, non-governmental organizations which favor the use of violence to achieve political goals may provide public goods in order to gain political support (see, for example, Berman and Laitin, 2008, and Berman, 2009). Many observers have claimed that Hamas has used this approach to gain political support in the Palestinian context. Adding to equation (1) indicators for the operation in the locality of charity organizations, culture clubs, and sports clubs (information was taken from Palestinian Central Bureau of Statistics, 1999) yielded insignificant results.
} 
to reach their workplaces. Palestinian employment in Israel started to recover slowly after operation "Defensive Shield".

The Second Intifada had a strong negative effect on economic conditions in the West Bank. Per capita real gross national product in the West Bank was 22 percent lower in 2002, at the height of the Intifada, than in 2000. The average unemployment rate in 2002 was 28.2 percent, up from 7.5 percent in the third quarter of 2000, just prior to the outbreak of the Intifada. Wages also declined. This affected mostly uneducated workers, many of whom were employed in Israel at wages higher than those prevalent in the West Bank (for more on this see International Monetary Fund, 2003; World Bank, 2004; and Mansour, 2010; Miaari and Sauer, 2011).

\section{Employment restrictions and political violence}

In this section we examine how the policy adopted by Israel at the start of the Second Intifada of drastically reducing Palestinian employment within its borders affected Palestinian involvement in the conflict during the first eighteen months of the Intifada. Identification relies on two facts established in the previous section: (a) that variation across Palestinian localities in pre-Intifada rates of employment by permit was considerable and (b) that this variation was unrelated to prior levels of involvement in the conflict. ${ }^{14}$

Before turning to the econometric analysis, we provide a graphical illustration of the relationship between the decline in employment rates and Palestinian involvement in the Intifada: Figure 4 suggests that the sharper the decline was in the employment rate due to the Israeli policy change, the greater was the involvement of Palestinians in the conflict.

\section{[Figure 4]}

In order to investigate the relationship between employment restrictions and involvement in the conflict we estimate the following equation:

$$
F_{i}=\beta_{0}+\beta_{1} \Delta E R_{i}+\beta_{2} P_{i}+\beta_{3} U_{i}+\beta_{4} R C_{i}+\beta_{5} X_{i}+\beta_{6} A_{i}+\beta_{7} F(-1)_{i}+\eta_{i}
$$

where $F_{i}$ is the number of Palestinians killed by Israelis from the outbreak of the Second Intifada (September 28, 2000) until the start of operation "Defensive Shield" (March 29, 2002)

\footnotetext{
${ }^{14}$ We note that according to Palestinian labor force surveys, the decline in locality level employment in Israel with and without a permit was highly correlated (0.76). This reflects the high pre-Intifada correlation in employment with and without a permit, as mentioned in the previous section. Thus while our analysis focuses on the decline in employment with a permit, it is likely that similar results would have been obtained had we examined both types of employment. However, it is important to note that the sample size in the Palestinian labor force survey (which reports both types of employment) is not large enough to reliably reflect conditions at each locality.
} 
in locality $i, \Delta E R_{i}$ is the decline (in percentage points) from June-August 2000 to OctoberDecember 2000, in the average monthly employment by permit in Israel of Palestinian males ages 20-49 out of total male population in that age group in locality $i,{ }^{15} X_{i}$ is a vector of socio-demographic characteristics of the locality (the pre-Intifada unemployment rate, the share of males with up to elementary education, and the share of households with more than 8 persons), $F(-1)_{i}$ is the number of Palestinians killed by Israelis from the signing of the Oslo accords until the outbreak of the Second Intifada in locality $i$, and the other variables are defined as before. $\eta_{i}$ is a well-behaved error term.

The focus of our investigation is the parameter $\beta_{1}$. A positive $\beta_{1}$ implies that sharper policy-induced employment rate declines led to greater involvement of Palestinians in the conflict.

Following the previous literature (e.g. as discussed in Krueger and Laitin, 2008), we estimate the equation using a Zero-Inflated Negative Binomial (ZINB) regression. This method is appropriate for analyzing count data which is characterized by overdispersion and a large share of zeros in the dependent variable (see Long and Frees, 2006). ${ }^{16}$ Similar results were obtained using two alternative estimation techniques: Negative Binomial and (left-censored) Tobit. ${ }^{17}$

Our baseline results, presented in Table 3A, suggest that the Israeli employment restrictions led to a rise in the number of Palestinian fatalities during the Intifada. This result is consistent across the different specifications presented in the table. We also find that, all else being equal, there were more fatalities in larger localities and in cities (relative to villages). The last result is in line with existing literature (e.g. Savitch and Ardashev, 2001, and Kis-Katos et al., 2011) which relates it to several characteristics of urban areas: greater ability to hide and to plan and carry out acts of violence in a target-rich environment; greater exposure of the public to events which may increase support for combatants; factors that encourage political and social instability, such as fast rates of socio-demographic and economic changes, prevalence of poverty, and the existence of a large number of distinct communities in competition with each other. We also find that the number of fatalities was significantly larger in refugee camps, not only relative to villages, but also relative to cities. This may be related to pre-existing differences in political views across the three types of localities.

\section{[Table 3A]}

\footnotetext{
${ }^{15}$ We exclude September 2000 from the employment rate averages since the Intifada started in the last few days of the month.

${ }^{16}$ In 64 percent of all localities in our dataset there were no Palestinian fatalities during the period under investigation.

${ }^{17}$ The Vuong (1989) test indicates that ZINB should be preferred over the Negative Binomial and Poisson models.
} 
With respect to locality level differences in socio-demographic and economic characteristics, we find that the pre-Intifada rate of unemployment is not correlated with the number of fatalities during the Intifada. ${ }^{18}$ The results indicate that the number of fatalities is smaller in localities with lower levels of education. This is consistent with previous findings in the literature (Krueger and Maleckova, 2003 and Berrebi, 2007). We do not find a significant relationship between the number of fatalities and the share of households with more than eight persons, which is an indirect measure of poverty.

An interesting finding is that the number of fatalities was larger in localities that exhibited greater support of Yasser Arafat in the 1996 elections for the presidency of the Palestinian National Authority. This finding fits well with the claim that paramilitary forces close to Arafat and his Fatah movement, such as the Tanzim and the al-Aqsa Martyrs' Brigades, were leading the confrontation at the beginning of the Intifada (see Knesset - Research and Information Center, 2004). We find no significant relationship at the locality level between the total number of fatalities in the Intifada period and in the pre-Intifada period. ${ }^{19}$

As noted in the previous section, the outbreak of the Intifada brought about a decline not only in the number of Palestinians working in Israel but also in the number of work days per employee, implying that the decline in labor input was even greater than the decline in the number of workers (compare Appendix Figure A2 to Figure 1). To check whether this affects our conclusions, we re-estimate equation (2), adjusting the definition of $\Delta E R_{i}$ to reflect the decline in the number of work days per employee. The adjustment is based on the locality-specific average number of work days per employee in the pre-Intifada period. Results of this analysis, presented in Table 3B, are very similar to those obtained in the baseline specifications.

\footnotetext{
${ }^{18}$ Because labor force surveys do not allow us to compute the unemployment rate for all localities, we use instead the unemployment rate at the district level.

${ }^{19}$ Insignificant results are obtained as well when replacing pre-Intifada total fatalities with civilian and combatant fatalities.

We used the specification of equation (2) to test three additional hypothesis. In all cases there was no effect on our main result regarding the relationship between employment rate declines and involvement in the conflict.

First, one may be concerned that distance to Israel matters not just through its effect on the employment rate but also directly. Adding the log of distance to Israel to the estimated equation yielded an insignificant result.

Second, to take into account potential frictions between Jewish settlers and their Palestinian neighbors we added a variable capturing the distance between each Palestinian locality and the closest Israeli West Bank settlement. This variable turned out to be insignificant

Third, following the Oslo agreements, the West Bank was divided into three distinct areas: area A - under Palestinian security and civilian control; area B - under Israeli security control and Palestinian civilian control; area $\mathrm{C}$ - under Israeli security and civilian control. We find that the number of fatalities in areas $\mathrm{B}$ and $\mathrm{C}$ was significantly lower than in area $\mathrm{A}$. This is likely due to the greater ability of Israeli security forces to operate in areas B and C.
} 


\section{[Table 3B]}

Until now we defined $\Delta E R_{i}$ as the locality level change, from June-August 2000 to October-December 2000, in the average employment rate. As Figure 1 shows, however, the employment rate continued to fluctuate after December 2000, and this pattern may have varied by locality. To check whether this undermines our conclusions, we re-estimate equation (2), adjusting the definition of $\Delta E R_{i}$ to reflect the decline in the average employment rate from June-August 2000 to the period October 2000-March 2002. ${ }^{20}$ Results of this analysis, presented in Table 3C, are very similar to those presented in Table 3A. We note that locality level employment rates during the first phase (eighteen months) of the Intifada may be endogenous to conflict intensity, and thus it is seems that the baseline specification - which takes into account only the first three months of the Intifada - should be preferred.

\section{[Table 3C]}

One may argue that the relationship between employment and involvement in the conflict is inherently different across types of localities and that this is not being taken into account in our analysis. To address this concern we re-estimate equation (2) solely for villages, which make up 72 percent of the localities in our dataset. We find (Table 3D) that the effect of employment restrictions on involvement in the conflict is stronger for villages than for the entire set of localities.

\section{[Table 3D]}

In Table 4 we present a summary of the marginal effects - at the sample means of the explanatory variables - of the decline in employment rates on the number of fatalities as derived from estimating equation (2) using different definitions of $F_{i}$ (total, civilian, and combatant fatalities $\left.{ }^{21}\right)$ as well as different definitions of $\Delta E R_{i}$ by employee age groups (2049, 20-34, and 35-49). We estimate equation (2) for the different age groups for the following reasons: (a) the restrictions on employment in Israel imposed following the outbreak of the Intifada were much stricter for the younger Palestinian workers (20-34) than for their older colleagues (35-49) and (b) previous research has shown that the young are typically more heavily involved in violence (see Krueger and Maleckova, 2003; Berrebi, 2007; and Krueger, 2008).

\footnotetext{
${ }^{20}$ For the localities included in our dataset, the correlation between the average employment rates in the periods October-December 2000 and October 2000-March 2002 is 0.84 .

${ }^{21}$ It is practically impossible to estimate equation (2) when defining $F_{i}$ as the number of Palestinian suicide bombers as their numbers are too small.
} 


\section{[Table 4]}

Looking first at total fatalities and at workers aged 20-49, we find that a one percentage point decrease in the locality-specific employment rate resulted in an additional 0.12 fatalities. When aggregating this effect for the entire set of localities in our dataset, this translates into 148 fatalities, or about one fifth of total fatalities during the period under consideration. ${ }^{22}$ Consistent with the existing literature, we find that the effect on the total number of fatalities from the Israeli imposed employment restrictions was much stronger for young Palestinian workers (0.146) than for older ones (0.057). We also find that the decline in employment opportunities for the young workers had a larger and statistically more robust effect on combatant fatalities than on civilian fatalities, and that the opposite is true for older workers.

\section{Conclusion}

Policy makers, researchers and the general public are interested in learning how economic conditions affect political violence and conflict. Such knowledge can inform the design of policies aimed at countering violence. Conventional wisdom holds that poor economic conditions are one of the root causes of violence and conflict, and this view seems to underlie policies undertaken by governments around the world to reduce violence. However, academic research has not reached a consensus regarding the causal relationship between economic conditions and conflict.

This paper relies on detailed data and a "natural experiment" to address this question in the context of the Israeli-Palestinian conflict. Employment in Israel was a major source of income for Palestinians before the outbreak of the Second Intifada in 2000, accounting for about one sixth of Palestinian national income. Following the outbreak of the Intifada Israel imposed severe restrictions on the employment of Palestinians within its borders. We examine how this abrupt and drastic policy change affected the involvement of West Bank Palestinians in fatal confrontations in the first phase of the Intifada. Identification relies on the fact that variation in pre-Intifada employment rates in Israel across Palestinian localities was not only considerable but also unrelated to prior levels of involvement in the conflict.

Our analysis shows that the Israeli employment restrictions led to an increase in conflict intensity: at the locality level, a one percentage point decrease in the employment rate of

\footnotetext{
${ }^{22}$ To arrive at the figure of 148 fatalities we multiply the marginal effect (0.12) by the average decline in the employment share (3.3 percentage points) and by the total number of localities (373):

$0.12 \times 3.3 \times 373=148$.
} 
males ages 20-49 led to a 0.12 increase in the number of fatalities. Back of the envelope calculations show that the decline in employment can explain roughly one fifth of all Palestinian fatalities. Subject to several caveats mentioned in the introduction, these results suggest that allowing a greater number of Palestinian workers into Israel may not only improve the welfare of Palestinians, but may also help in reducing their involvement in the conflict with Israel.

\section{References}

Abadie, A. (2006), "Poverty, Political Freedom, and the Roots of Terrorism", American Economic Review Papers and Proceedings, 96(2), pp. 50-56.

Benmelech, E., Berrebi, C. and Klor, E. (2010), "Counter-Suicide-Terrorism: Evidence from House Demolitions", NBER Working Paper No. 16493.

Berda, Yael. (Forthcoming), The Bureaucracy of the Occupation: The Permit Regime in the West Bank 2000-2006. Jerusalem and Tel Aviv: The Van Leer Institute and Hakibbutz Hameuchad. [in Hebrew]

Berman, E. (2009), Radical, Religious, and Violent: The New Economics of Terrorism, The MIT Press, Cambridge, Massachusetts.

— and Laitin, D.D. (2008), "Religion, Terrorism and Public Goods: Testing the Club Model", Journal of Public Economics, 92(10-11), pp. 1942-1967.

—, Callen, M., Felter, J.H. and Shapiro, J.N. (2009), "Do Working Men Rebel? Insurgency and Unemployment in Iraq and the Philippines", NBER Working Paper No. 15547.

-, Shapiro, J.N. and Felter, J.H. (2011), "Can Hearts and Minds Be Bought? The Economics of Counterinsurgency in Iraq", Journal of Political Economy, 19(4), pp. 766-819.

Berrebi, C. (2007), "Evidence about the Link between Education, Poverty and Terrorism among Palestinians", Peace Economics, Peace Science and Public Policy, 13(1), Article 2 .

Blomberg, S.B., Hess, G.D. and Weerapana, A. (2004), "Economic Conditions and Terrorism", European Journal of Political Economy, 20, pp. 463-478.

Brophy-Baermann, B. and Conybeare, J.A.C. (1994), "Retaliating against Terrorism: Rational Expectations and the Optimality of Rules versus Discretion", American Journal of Political Science, 38(1), pp. 196-210.

Enders, W. and Sandler, T. (1993), "The Effectiveness of Antiterrorism Policies: A Vector-Autoregression Intervention Analysis", The American Political Science Review, 87(4), pp. $829-844$. 
Gazit, S. (1995), The Carrot and the Stick: Israel's Policy in Judea and Samaria, 1967-68, Washington, D.C. : B'nai B'rith Books.

Haushofer, J., Biletzki, A. and Kanwisher, N. (2010), "Both Sides Retaliate in the Israeli-Palestinian Conflict", Proceedings of the National Academy of Science, 107, pp. 17927-17932.

International Monetary Fund, (2003), West Bank and Gaza: Economic Performance and Reform under Conflict Conditions, September.

Iyengar, R., Monten, J. and Hanson, M. (2011), "Building Peace: the Impact of Aid on the Labor Market for Insurgents", NBER Working Paper No. 17297.

Jaeger, D.A. and Paserman, M.D. (2008), "The Cycle of Violence? An Empirical Analysis of Fatalities in the Palestinian-Israeli Conflict", American Economic Review, 98(4), pp. 1591-1604.

Kaplan, E.H., Mintz, A., Mishal, S. and Samban, C. (2005) "What Happened to Suicide Bombings in Israel? Insights from a Terror Stock Model", Studies in Conflict $\&$ Terrorism, 28(3), pp. 225-235.

Kis-Katos, K., Liebert, L. and Schulze, G.G. (2111), "On the Origin of Domestic and International Terrorism", European Journal of Political Economy, 27(supplement 1), pp. S17-S36.

Knesset - Research and Information Center (2004), Terrorist Organizations Fighting Israel [in Hebrew].

Krueger, A.B. (2008), "What Makes a Homegrown Terrorist? Human Capital and Participation in Domestic Islamic Terrorist Groups in the U.S.A.", Economics Letters, 101(3), pp. 293-296.

—, and Maleckova, J. (2003), "Education, Poverty and Terrorism: Is There a Causal Connection?", Journal of Economic Perspectives, 17(4), pp. 119-144.

—, and Laitin, D.D. (2008), "Kto Kogo?: A Cross-Country Study of the Origins and Targets of Terrorism", In P. Keefer and N. Loayza (eds.), Terrorism, Economic Development, and Political Openness. Cambridge University Press and The World Bank, New York.

Long, J.S. and Freese, J. (2006), Regression Models for Categorical Dependent Variables Using STATA, 2nd Edition, A STATA Press Publication, STATA Corporation, Texas.

Lyall, J. (2009), "Does Indiscriminate Violence Incite Insurgent Attacks? Evidence from a Natural Experiment", Journal of Conflict Resolution, 53(3), pp. 331-362.

Mansour, H. (2010), "The Effects of Labor Supply Shocks on Labor Market Outcomes: Evidence from the Israeli-Palestinian Conflict", Labour Economics, 17(6), pp. 930-939.

Miaari, S.H., and Sauer, R.M. (2011), "The Labor Market Costs of Conflict: Closures, Foreign Workers, and Palestinian Employment and Earnings", Review of Economics 
of the Household, 9(1), pp. 129-148.

Miguel, E., Satyanath, S. and Sergenti, E. (2004), "Economic Shocks and Civil Conflict: An Instrumental Variables Approach", Journal of Political Economy, 112(4), pp. 725-753.

Mundlak, G. (2000), "Power-Breaking or Power-Entrenching Law? The Regulation of Palestinian Workers in Israel", Comparative Labor Law and Policy Journal, 20(4), pp. 569-620.

Palestinian Central Bureau of Statistics. (1999), Local Community Survey - 1998 Databases.

- (2000), Labour Force Survey: Main Findings (July - September, 2000 Round), Labour Force Survey Report Series (No. 18).

- (2003), National Accounts at Current and Constant Prices (1994-2000).

Saleh, B.A. (2004), "Economic Conditions and Resistance to Occupation in the West Bank and Gaza Strip: There is a Causal Connection", Topics in Middle Eastern and North African Economics, 6.

- (2009), "An Econometric Analysis of Palestinian Attacks: An Examination of Deprivation Theory and Choice of Attacks", European Journal of Social Sciences, 7(4), 17-29.

Savitch, H.V. and Ardashev, G. (2001), "Does Terror Have an Urban Future?", Urban Studies, 38(13), pp. 2515-2533.

Sayre, E.A. (2009), "Labor Market Conditions, Political Events, and Palestinian Suicide Bombings", Peace Economics, Peace Science and Public Policy, 15(1), pp. 1-26.

State of Israel (2011), Report of the Committee on the Employment of Palestinian Workers in Israel. [in Hebrew]

Tavares, J. (2004), "The Open Society Assesses its Enemies: Shocks, Disasters and Terrorist Attacks", Journal of Monetary Economics, 51(5), pp. 1039-1070.

Vuong, Q.H. (1989), "Likelihood Ratio Tests for Model Selection and Non-Nested Hypotheses", Econometrica, 57(2), pp. 307-333.

World Bank. (2004), Four Years - Intifada, Closures and Palestinian Economic Crisis, an Assessment.

Zussman, A. and Zussman, N. (2006), "Assassinations: Evaluating the Effectiveness of an Israeli Counterterrorism Policy Using Stock Market Data", Journal of Economic Perspectives, 20(2), pp. 193-206. 


\section{APPENDIX}

\section{Figure 1A: PRE-INTIFAdA EMPLOYMENT RATES BY WEST BANK DisTRICT AND Locality TyPe - City/Refugee CAMP (Village), in PERCENT}

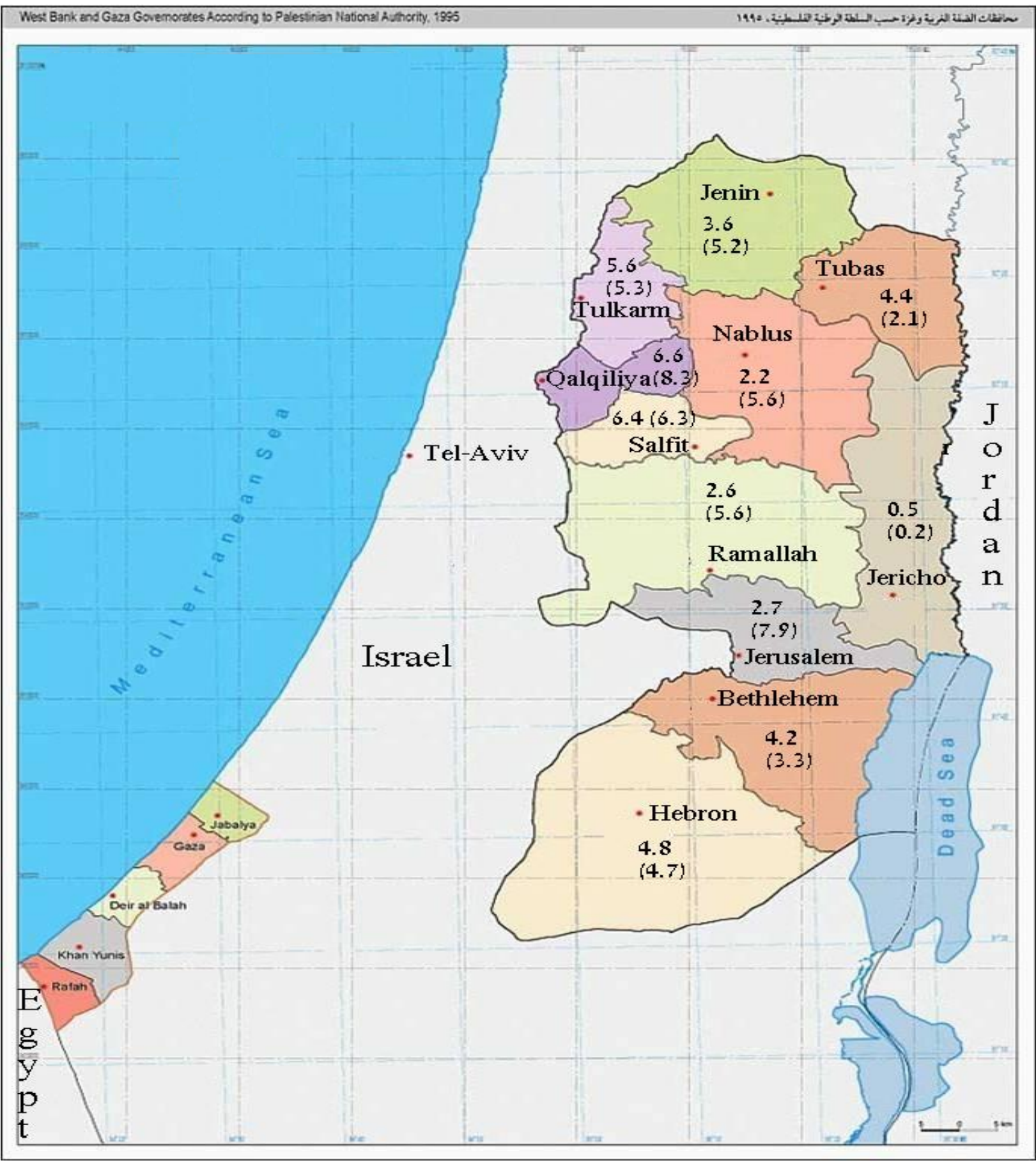

Notes: Pre-Intifada employment rate refers to June-August 2000 average monthly employment by permit in Israel of Palestinian males ages 20-49 out of total male population in that age group in each district. Jerusalem district excludes East Jerusalem. 
Figure 2A: DAYs Worked By WeSt BANK PALESTINIANS EMPlOyed IN ISRAEL WITH A PERMIT, 1999-2005



Notes: Employment figures are monthly averages per quarter. 
TABle 1: Summary Statistics for West BANK PALESTinian Localities

(shares, unless otherwise noted)

\begin{tabular}{|c|c|c|c|c|c|c|c|}
\hline & & $\begin{array}{l}\text { Data } \\
\text { source }^{1}\end{array}$ & $\mathrm{~N}$ & Mean & $\begin{array}{l}\text { Standard } \\
\text { deviation }\end{array}$ & Min & Max \\
\hline \multicolumn{2}{|c|}{ Employment by permit before the outbreak of the Intifada ${ }^{2}$} & a & 373 & 0.052 & 0.051 & 0 & 0.523 \\
\hline \multicolumn{2}{|c|}{ Distance to Israel (km) } & $\mathrm{b}$ & 373 & 12.6 & 7.6 & 1.0 & 35.3 \\
\hline \multicolumn{2}{|c|}{ Minimum distance to Israeli settlement (km) } & $\mathrm{b}$ & 373 & 3.3 & 1.8 & 0.0 & 11.0 \\
\hline \multirow[t]{3}{*}{ Locality type } & City & c & 373 & 0.25 & 0.43 & 0 & 1 \\
\hline & Refugee camp & c & 373 & 0.03 & 0.17 & 0 & 1 \\
\hline & Village & c & 373 & 0.72 & 0.45 & 0 & 1 \\
\hline \multicolumn{2}{|c|}{ Population (thousands) } & c & 373 & 4.0 & 9.1 & 0.2 & 119.0 \\
\hline \multicolumn{2}{|c|}{ Refugees } & c & 373 & 0.21 & 0.24 & 0 & 0.99 \\
\hline \multirow{9}{*}{$\begin{array}{l}\text { Socioeconomic } \\
\text { characteristics }\end{array}$} & Households with more than 8 persons & c & 373 & 0.32 & 0.08 & 0.09 & 0.64 \\
\hline & Males with up to elementary education & c & 373 & 0.53 & 0.09 & 0.27 & 0.85 \\
\hline & Pre-Intifada unemployment rate ${ }^{3}$ & c & 373 & 0.07 & 0.04 & 0.03 & 0.14 \\
\hline & Church & c & 372 & 0.07 & 0.25 & 0 & 1 \\
\hline & Charity organization & c & 372 & 0.39 & 0.49 & 0 & 1 \\
\hline & Culture club & c & 372 & 0.20 & 0.40 & 0 & 1 \\
\hline & Sports club & c & 372 & 0.48 & 0.50 & 0 & 1 \\
\hline & Coffee shop & c & 372 & 0.38 & 0.49 & 0 & 1 \\
\hline & Restaurant & c & 372 & 0.40 & 0.49 & 0 & 1 \\
\hline \multirow{4}{*}{$\begin{array}{l}\text { Availability of } \\
\text { public utilities }\end{array}$} & Electricity & $\mathrm{d}$ & 373 & 0.93 & 0.26 & 0 & 1 \\
\hline & Water & $\mathrm{d}$ & 373 & 0.73 & 0.44 & 0 & 1 \\
\hline & Sewage & $\mathrm{d}$ & 373 & 0.10 & 0.30 & 0 & 1 \\
\hline & Telephone (landline) & $\mathrm{d}$ & 373 & 0.75 & 0.44 & 0 & 1 \\
\hline \multicolumn{2}{|c|}{ Pre-Intifada support for Arafat ${ }^{4}$} & e & 336 & 0.64 & 0.17 & 0.21 & 0.97 \\
\hline \multicolumn{2}{|c|}{ Fatalities before the outbreak of the Intifada ${ }^{5}(\%)$} & $\mathrm{f}$ & 373 & 0.01 & 0.02 & 0 & 0.15 \\
\hline \multicolumn{8}{|c|}{ Fatalities after the outbreak of the Intifada ${ }^{6}$ : } \\
\hline \multirow[t]{3}{*}{ Share (\%) } & Total & g & 373 & 0.034 & 0.093 & 0 & 1.410 \\
\hline & - Civilians & g & 373 & 0.021 & 0.059 & 0 & 0.822 \\
\hline & - Combatants & $\mathrm{g}$ & 373 & 0.013 & 0.044 & 0 & 0.587 \\
\hline \multirow[t]{3}{*}{ Absolute numbers } & Total & g & 373 & 2.23 & 8.29 & 0 & 73 \\
\hline & - Civilians & g & 373 & 1.37 & 5.30 & 0 & 50 \\
\hline & - Combatants & g & 373 & 0.86 & 3.30 & 0 & 33 \\
\hline
\end{tabular}

Source: See text for details.

Notes:

${ }^{1}$ a - Israeli Ministry of Industry, Trade and Labor; b - Israeli Central Bureau of Statistics; c - Palestinian Central Bureau of Statistics (1997 census); d -

Palestinian Central Bureau of Statistics (1999); e - Palestinian Central Elections Committee; f - B'Tselem (The Israeli Information Center for Human Rights in the Occupied Territories) and the Israeli daily newspapers Ha'aretz and Yedioth Ahronoth; g - B'Tselem, International Institute for Counter-Terrorism, the Israeli daily newspapers Ha'aretz and Yedioth Ahronoth.

${ }^{2}$ June-August 2000 average monthly employment by permit in Israel of Palestinian males ages 20-49 out of total male population in that age group in each locality.

${ }^{3}$ At the district level, Q3 2000.

${ }^{4}$ In elections for the presidency of the Palestinian National Authority held in January 1996.

${ }^{5}$ Palestinians killed by Israelis from the signing of the Oslo accords (September 13, 1993) until the outbreak of the Second Intifada (September 28, 2000) out of total population in locality.

${ }^{6}$ Palestinians killed by Israelis from the outbreak of the Second Intifada (September 28, 2000) until the start of operation "Defensive Shield" (March 29,

2002) out of total population in locality. 
TABLE 2: DETERMINANTS OF PRE-INTIFADA EMPLOYMENT RATES IN ISRAEL

\begin{tabular}{|c|c|c|c|c|c|c|c|}
\hline \multicolumn{8}{|c|}{ dependent variable: employment rate in locality } \\
\hline & & $(1)$ & $(2)$ & (3) & (4) & (5) & (6) \\
\hline \multirow{2}{*}{\multicolumn{2}{|c|}{ Log distance to Israel }} & $-2.022^{* * *}$ & $-2.012^{* * *}$ & $-2.020^{* * *}$ & $-2.022^{* * *}$ & $-2.018^{* * *}$ & $-2.001^{* * *}$ \\
\hline & & $(0.388)$ & $(0.399)$ & $(0.389)$ & $(0.388)$ & $(0.387)$ & $(0.398)$ \\
\hline \multirow{2}{*}{\multicolumn{2}{|c|}{ Population }} & -0.008 & -0.012 & -0.007 & -0.007 & -0.006 & -0.010 \\
\hline & & $(0.011)$ & $(0.011)$ & $(0.011)$ & $(0.011)$ & $(0.011)$ & $(0.011)$ \\
\hline \multirow[t]{4}{*}{ Locality type } & City & $-1.552^{* * *}$ & $-1.563^{* * *}$ & $-1.550^{* * *}$ & $-1.548^{* * *}$ & $-1.543^{* * *}$ & $-1.550^{* * *}$ \\
\hline & & $(0.471)$ & $(0.499)$ & $(0.471)$ & $(0.470)$ & $(0.469)$ & $(0.496)$ \\
\hline & Refugee camp & $-1.396^{*}$ & $-1.763^{* *}$ & $-1.392^{*}$ & $-1.344^{*}$ & $-1.341^{*}$ & $-1.720^{* *}$ \\
\hline & & $(0.712)$ & $(0.755)$ & $(0.715)$ & $(0.728)$ & $(0.732)$ & $(0.772)$ \\
\hline \multirow{2}{*}{\multicolumn{2}{|c|}{ Pre-Intifada support for Arafat }} & & -0.009 & & & & -0.008 \\
\hline & & & $(0.010)$ & & & & $(0.011)$ \\
\hline \multirow{6}{*}{$\begin{array}{l}\text { Fatalities } \\
\text { before the } \\
\text { outbreak } \\
\text { of the } \\
\text { Intifada }\end{array}$} & Combatants & & & -1.797 & & & \\
\hline & & & & $(22.022)$ & & & \\
\hline & Civilians & & & & -6.831 & & \\
\hline & & & & & (11.294) & & \\
\hline & Total & & & & & -5.584 & -8.212 \\
\hline & & & & & & (10.298) & (10.647) \\
\hline & 373 & 373 & 373 & 373 & 373 & 373 \\
\hline \multicolumn{2}{|l|}{ Adjusted $\mathrm{R}^{2}$} & 0.092 & 0.096 & 0.092 & 0.092 & 0.092 & 0.097 \\
\hline
\end{tabular}




\section{TABLE 3: EFFECT OF EMPLOYMENT RESTRICTIONS ON CONFLICT INTENSITY}

PANEL A: BASELINE SPECIFICATION

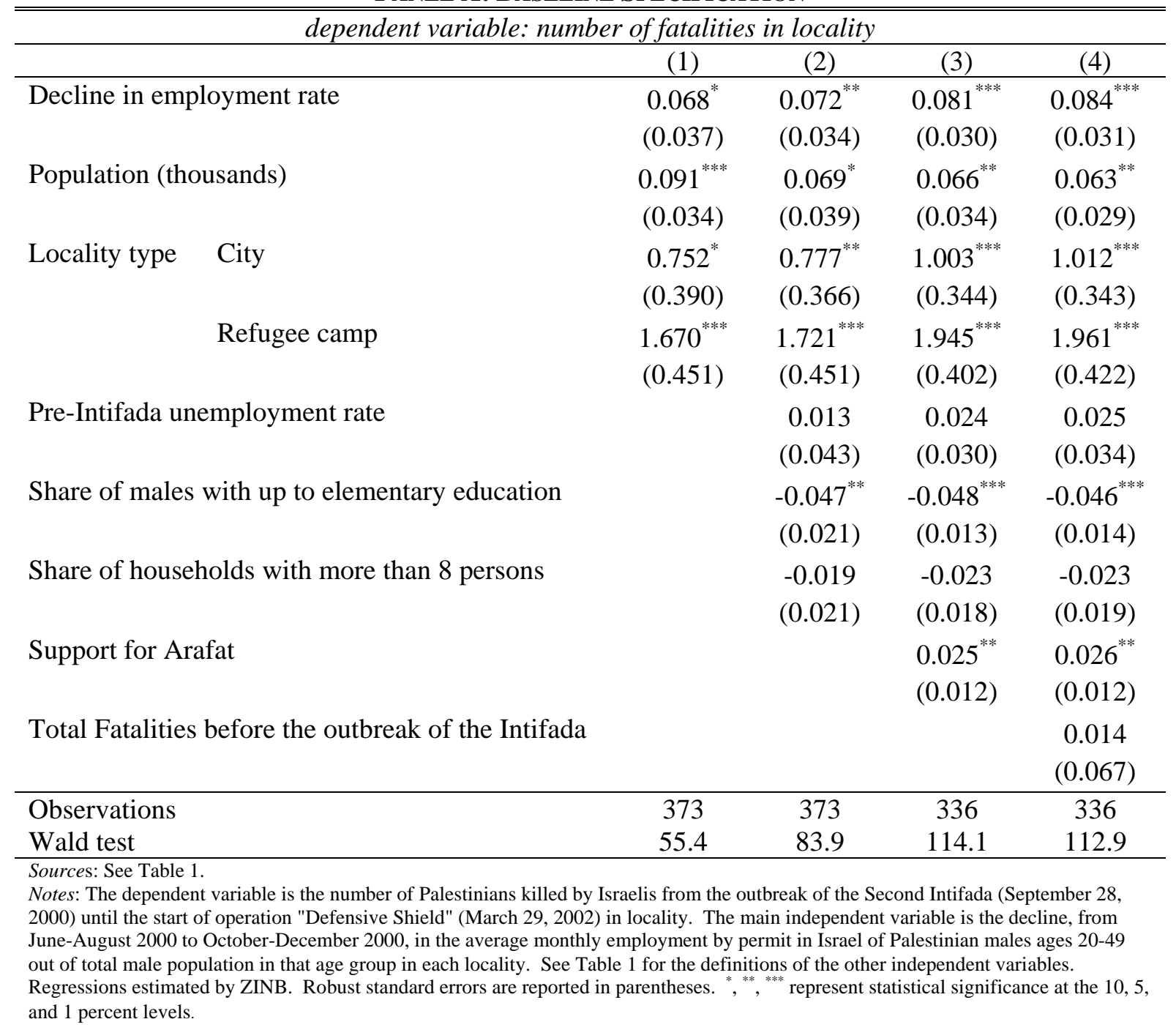




\section{TABLE 3: EFFECT OF EMPLOYMENT RESTRICTIONS ON CONFLICT INTENSITY PANEL B: TAKING INTO ACCOUNT CHANGES IN EMPLOYMENT INTENSITY}

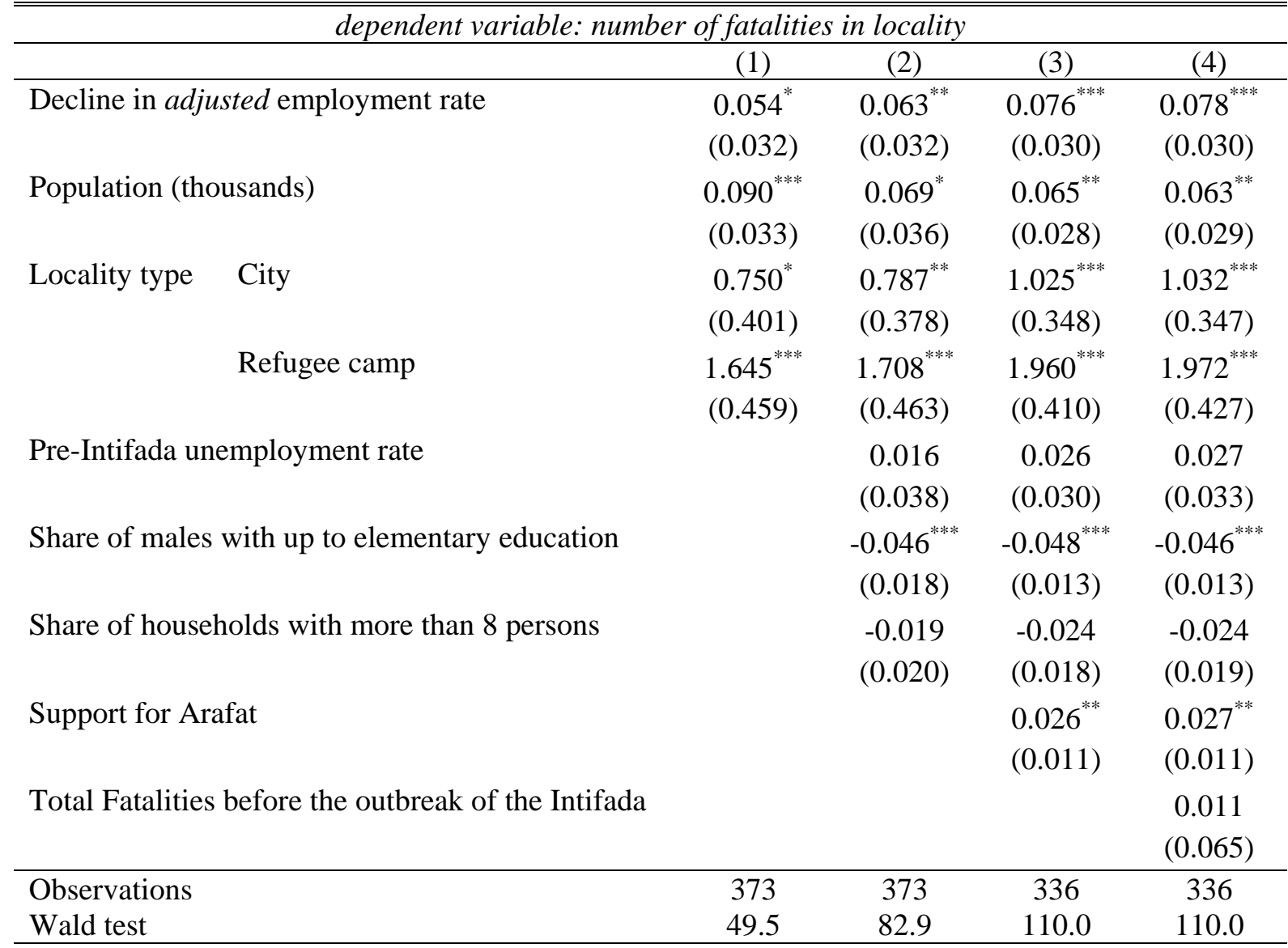

Sources: See Table 1.

Notes: The dependent variable is the number of Palestinians killed by Israelis from the outbreak of the Second Intifada (September 28, 2000) until the start of operation "Defensive Shield" (March 29, 2002) in locality. The main independent variable is the decline, from June-August 2000 to October-December 2000, in average monthly "full-time" employment by permit in Israel of Palestinian males ages 20-49 out of total male population in that age group in each locality; adjustment for "full time" employment is based on the average number of work days per employee in locality prior to the outbreak of the Second Intifada. See Table 1 for the definitions of the other independent variables. Regressions estimated by ZINB. Robust standard errors are reported in parentheses. ${ }^{*},{ }^{* *},{ }^{* * *}$ represent statistical significance at the 10,5 , and 1 percent levels. 


\section{TABLE 3: EFFECT OF EMPLOYMENT RESTRICTIONS ON CONFLICT INTENSITY PANEL C: COMPUTING DECLINE IN EMPLOYMENT OVER A LONGER HORIZON}

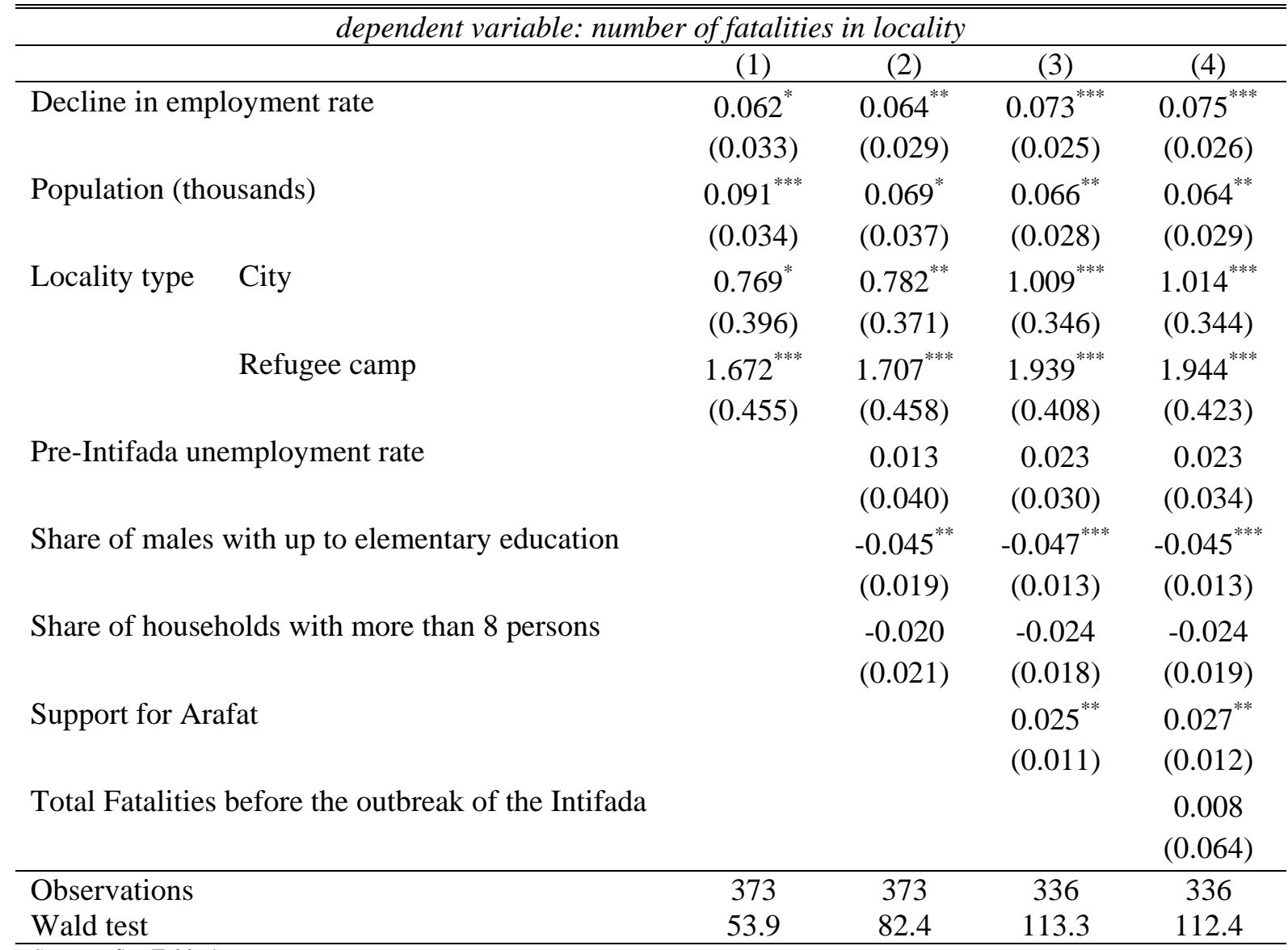

Sources: See Table 1.

Notes: The dependent variable is the number of Palestinians killed by Israelis from the outbreak of the Second Intifada (September 28, 2000) until the start of operation "Defensive Shield" (March 29, 2002) in a locality. The main independent variable is the decline, from June-August 2000 to October 2000-March 2002, in average monthly employment by permit in Israel of Palestinian males ages 20-49 out of total male population in that age group in each locality. See Table 1 for the definitions of the other independent variables.

Regressions estimated by ZINB. Robust standard errors are reported in parentheses. ${ }^{*},{ }^{* *},{ }^{* * *}$ represent statistical significance at the 10,5 , and 1 percent levels. 


\section{TABLE 3: EFFECT OF EMPLOYMENT RESTRICTIONS ON CONFLICT INTENSITY}

PANel D: Restricting ANALysis to VilLaGes

\begin{tabular}{|c|c|c|c|c|}
\hline \multicolumn{5}{|c|}{ dependent variable: number of fatalities in locality } \\
\hline & $(1)$ & $(2)$ & (3) & $(4)$ \\
\hline Decline in employment rate & $\begin{array}{l}0.115^{* *} \\
(0.047)\end{array}$ & $\begin{array}{l}0.086^{* * *} \\
(0.033)\end{array}$ & $\begin{array}{l}0.088^{* * *} \\
(0.034)\end{array}$ & $\begin{array}{l}0.097^{* * *} \\
(0.033)\end{array}$ \\
\hline Population (thousands) & $\begin{array}{c}0.000 \\
(0.000)\end{array}$ & $\begin{array}{c}0.000 \\
(0.000)\end{array}$ & $\begin{array}{c}0.000 \\
(0.000)\end{array}$ & $\begin{array}{c}0.000 \\
(0.000)\end{array}$ \\
\hline Pre-Intifada unemployment rate & & $\begin{array}{c}0.105 \\
(0.070)\end{array}$ & $\begin{array}{c}0.100 \\
(0.067)\end{array}$ & $\begin{array}{c}0.095 \\
(0.064)\end{array}$ \\
\hline Share of males with up to elementary education & & $\begin{array}{l}-0.037^{*} \\
(0.022)\end{array}$ & $\begin{array}{c}-0.038^{* *} \\
(0.019)\end{array}$ & $\begin{array}{c}-0.037^{* *} \\
(0.018)\end{array}$ \\
\hline Share of households with more than 8 persons & & $\begin{array}{l}0.022 \\
(0.02)\end{array}$ & $\begin{array}{c}-0.006 \\
(0.061)\end{array}$ & $\begin{array}{c}-0.004 \\
(0.041)\end{array}$ \\
\hline Support for Arafat & & & $\begin{array}{c}0.036 \\
(0.037)\end{array}$ & $\begin{array}{c}0.037 \\
(0.031)\end{array}$ \\
\hline Total Fatalities before the outbreak of the Intifada & & & & $\begin{array}{c}0.495 \\
(0.378)\end{array}$ \\
\hline Observations & 267 & 267 & 234 & 234 \\
\hline Wald test & 8.1 & 21.9 & 23.7 & 28.3 \\
\hline
\end{tabular}

Sources: See Table 1.

Notes: The dependent variable is the number of Palestinians killed by Israelis from the outbreak of the Second Intifada (September 28, 2000) until the start of operation "Defensive Shield" (March 29, 2002) in locality. The main independent variable is the decline, from June-August 2000 to October-December 2000, in the average monthly employment by permit in Israel of Palestinian males ages 20-49 out of total male population in that age group in each locality. See Table 1 for the definitions of the other independent variables.

Regressions estimated by ZINB. Robust standard errors are reported in parentheses. . ${ }^{* * *},{ }^{* * *}$ represent statistical significance at the 10, 5, and 1 percent levels. 
TABLE 4: MARgINAL EFFECTS OF EMPLOYMENT RESTRICTIONS ON CONFLICT INTENSITY

\begin{tabular}{lclll}
\hline \hline & & \multicolumn{3}{c}{ dependent variable } \\
\cline { 3 - 5 } & & $\begin{array}{l}\text { Total } \\
\text { fatalities }\end{array}$ & $\begin{array}{l}\text { Civilian } \\
\text { fatalities }\end{array}$ & $\begin{array}{l}\text { Combatant } \\
\text { fatalities }\end{array}$ \\
\hline Decline in employment rate in age group & $20-49$ & $0.120^{* * *}$ & $0.076^{*}$ & $0.064^{*}$ \\
& $20-34$ & $0.146^{* * *}$ & 0.077 & $0.095^{* * *}$ \\
& $35-49$ & $0.057^{* *}$ & $0.047^{* * *}$ & 0.025 \\
\hline
\end{tabular}

Sources: See Table 1.

Notes: The dependent variable is the number of total/civilian/combatant Palestinians killed by Israelis from the outbreak of the Second Intifada (September 28, 2000) until the start of operation "Defensive Shield" (March 29, 2002) in a locality. The main independent variable is the decline, from June-August 2000 to October-December 2000, in average monthly employment by permit in Israel of

Palestinian males ages 20-49 or 20-34 or 35-49 out of total male population in the corresponding age group in each locality. See Table 1 for the definitions of the other independent variables. Regressions estimated by ZINB. Robust standard errors are reported in

parentheses. ${ }^{*},{ }^{* *},{ }^{* * *}$ represent statistical significance at the 10,5 , and 1 percent levels. 
Figure 1: West Bank Palestinians EMPloyed IN ISRAel

WITH A PERMIT , 1999-2005

- Males Females



Notes: Employment figures are monthly averages per quarter. 
FIGURE 2: EMPLOYMENT RATE AND DISTANCE TO ISRAEL

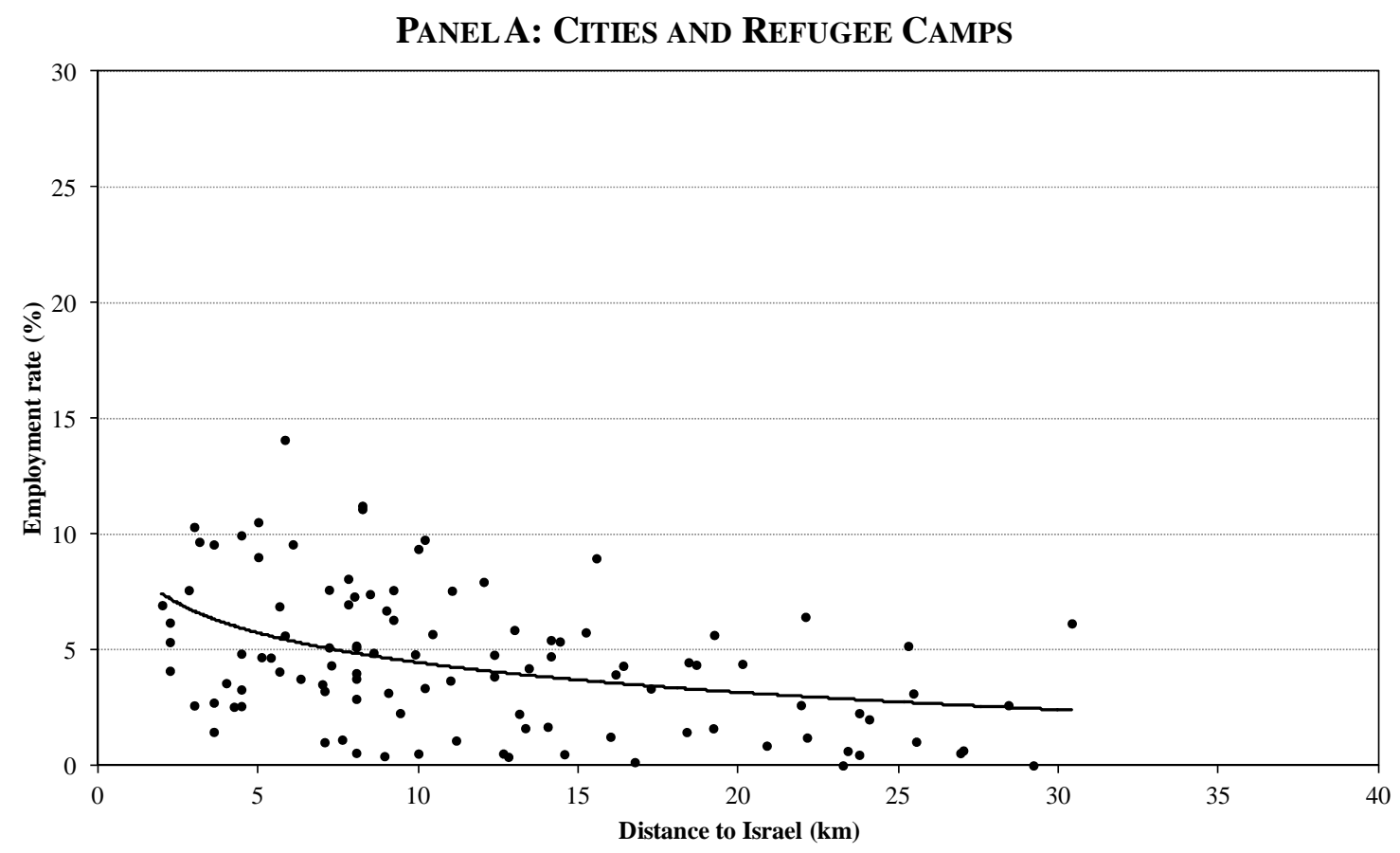

PANel B: Villages

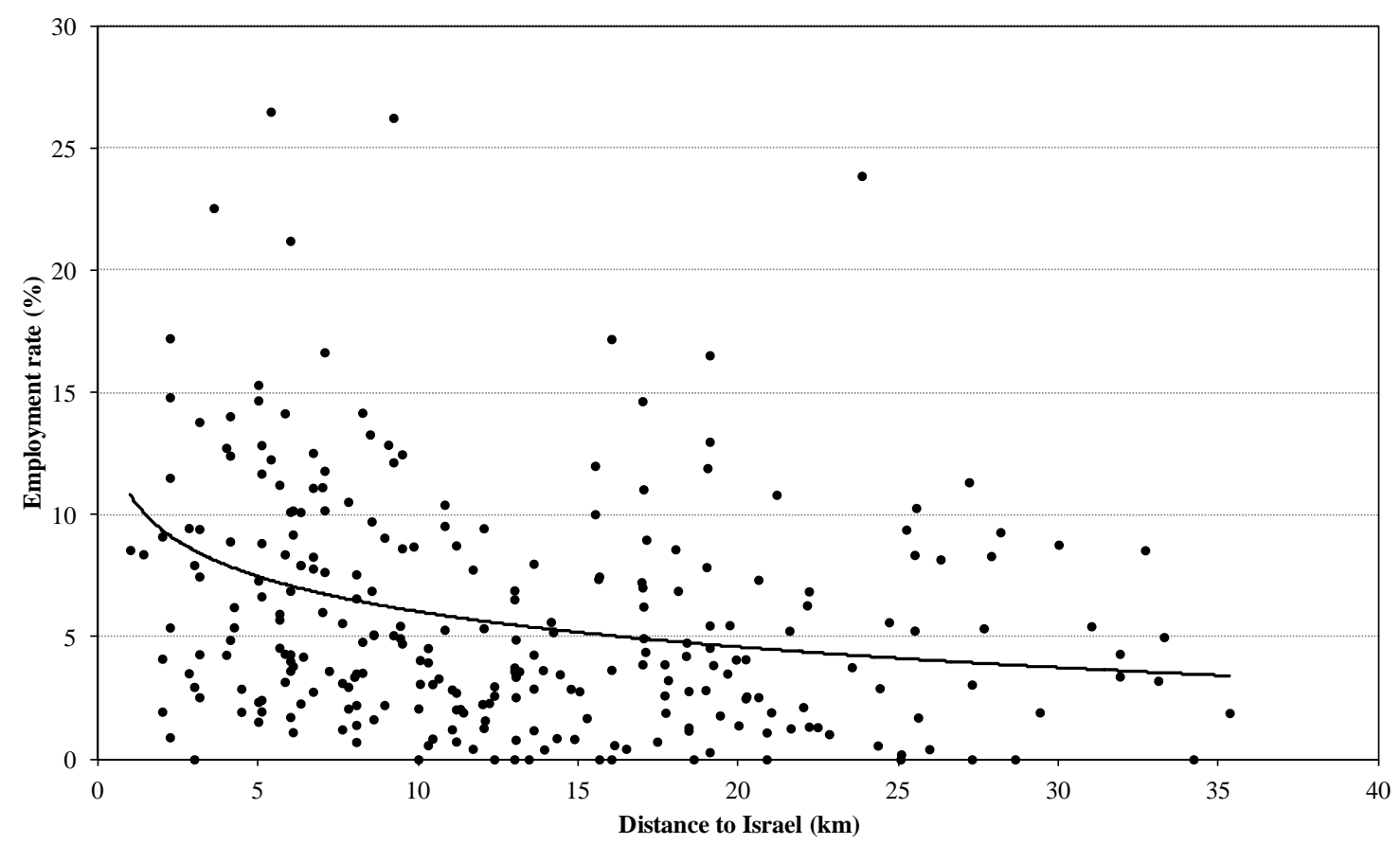

Notes: Employment rate refers to average monthly employment by permit in Israel of West Bank Palestinian males ages 20-49 out of total male population in that age group in each locality. Average employment is computed over the period October 1998-September 2000. Trendlines are logarithmic curves. 
Figure 3: FATAlities in The ISRAELI-PALESTINIAN CONFLiCT

Panel A: Palestinians Killed by IsRaelis

-West Bank - Gaza Strip

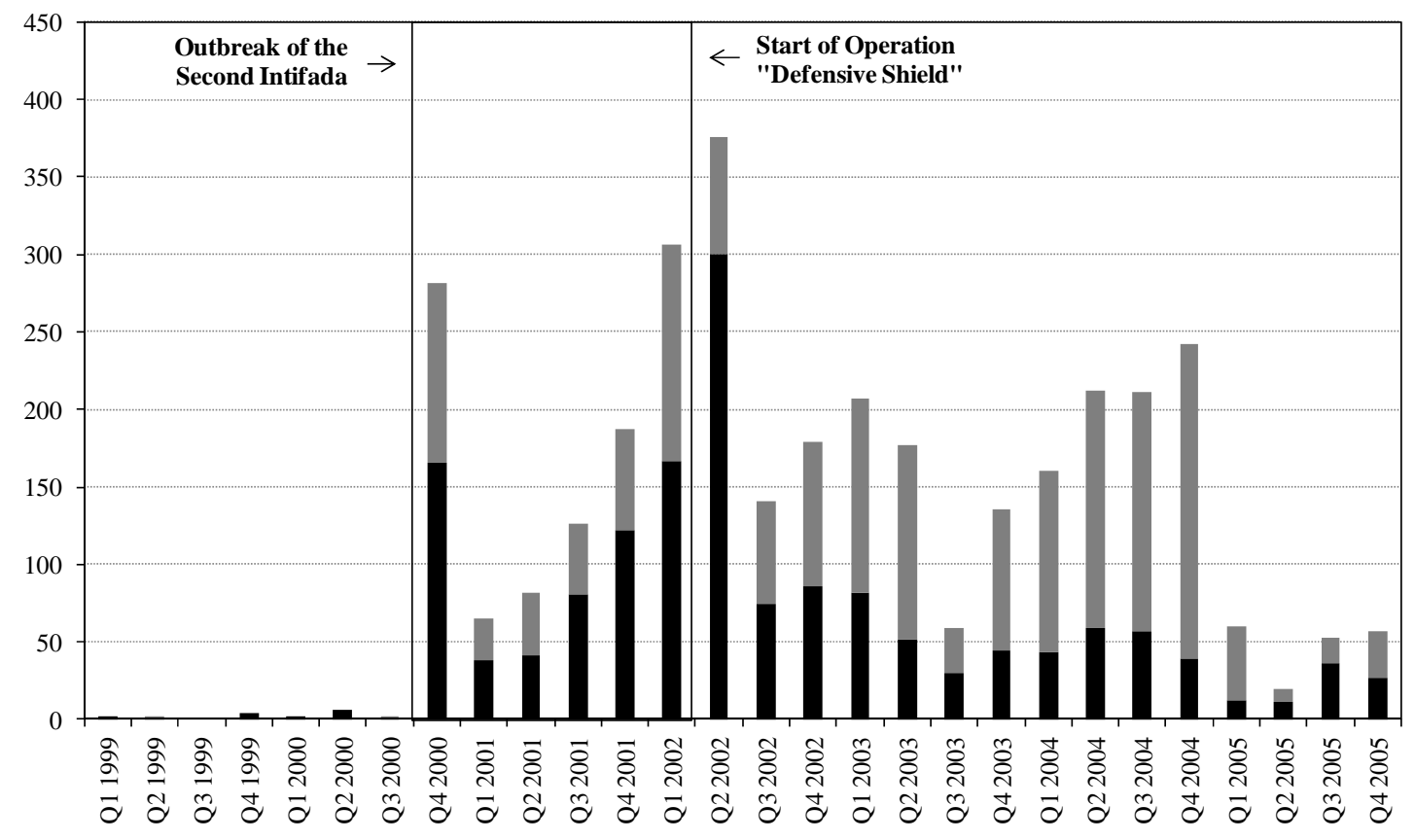

Panel B: Israelis Killed by Palestinians

- West Bank a Gaza Strip Israel

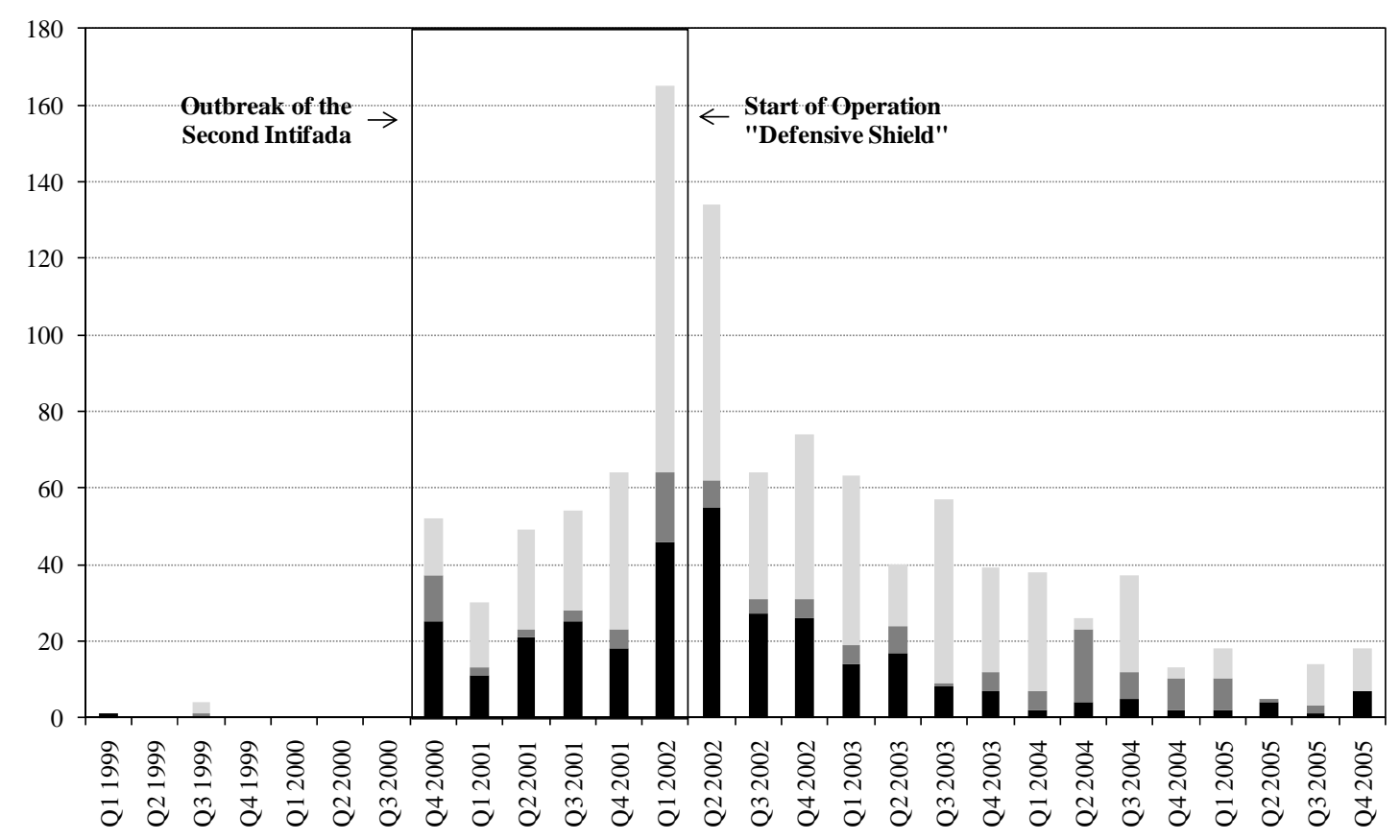

Notes: Figures for Q2 2000 include the last 3 days of September 2000, when the Intifada broke out; figures for Q2 2002 include the last 3 days of March 2002, when operation "defensive shield" started. 


\section{FigURE 4: DECLINE IN EMPLOYMENT AND CONFLICT INTENSITY}

Employment rate declined by up to 3 percentage points

Employment rate declined by 3-6 percentage points

- Employment rate declined by more than 6 percentage points

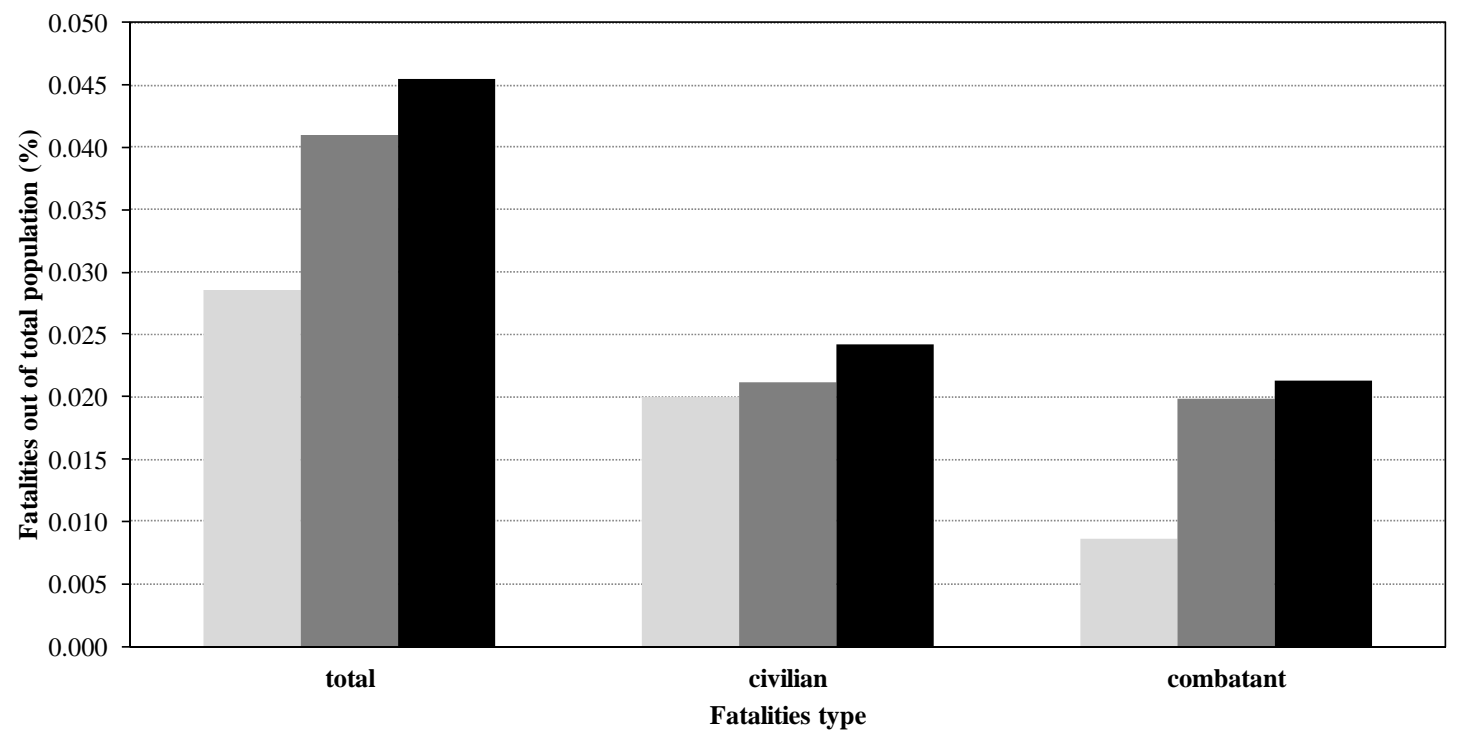

Notes: Employment rate refers to average monthly employment by permit in Israel of West Bank Palestinian males ages 20-49 out of total male population in that age group in each locality. Decline in employment rate is measured from June-August 2000 to October-December 2000. Fatality figures are for the period from the outbreak of the Second Intifada until the start of operation "Defensive Shield". 